\title{
Disability Policies In Pakistan: The Way Forward
}

\author{
Razia Gul \\ Department of Law \\ Abdul Wali Khan University
}

\begin{abstract}
This research article reflects policy development regarding disabled people in Pakistan. International efforts and policy development for the wellbeing of disabled people paved the way for generating debates and discussions on the condition and the rights of disabled people in Pakistan. Subsequently, laws have been enacted for the protection and promotion of the rights of disabled people in the country. Available literature on the polices related to disabled people have been critically reviewed and discussed. UN Convention on the Rights of Persons with Disabilities (CRPD) possesses immense and historic importance for inclusive society and it is being considered the first legally binding international treaty by which communities can hold their respective states for the enforcement of its articles and promote the quality of life of disabled people. Pakistan has ratified CRPD in the year 2011, following government's commitment to promote social, political, economic and civil rights of disabled people. In this regard, Pakistan enacted sporadic but important laws both in Provincial and National Assemblies. However, these policies could not bring about changes in the lives of disabled people. There is no proper mechanism at national and local level to implement the policies developed for the wellbeing of such downtrodden people.
\end{abstract}

Keywords: Disability, Inclusion, Accessibility, CRPD.

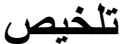

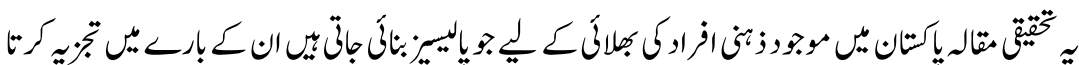

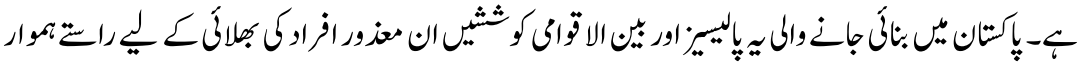

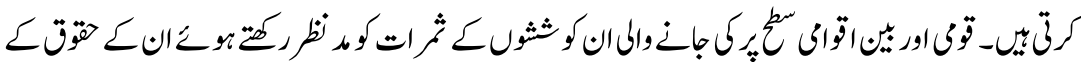

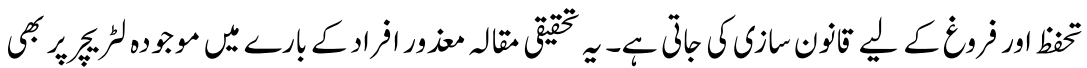

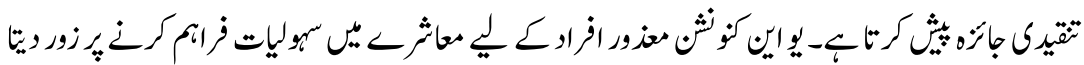

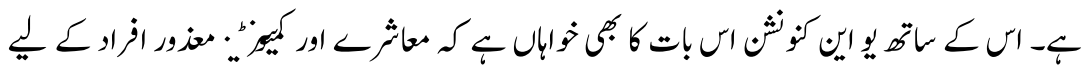

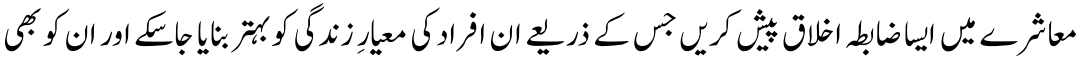

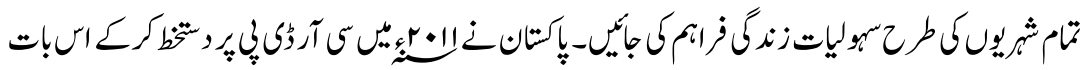

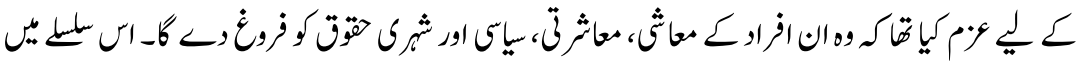

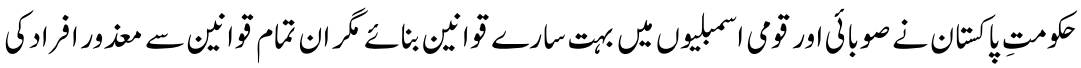




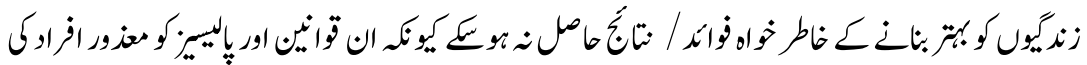

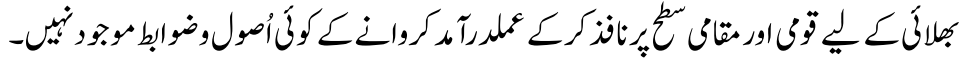

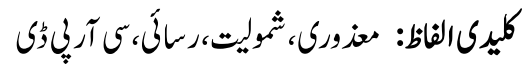

\section{Introduction}

More than one billion people live with disabilities across the globe. Whilst 80 percent of the disabled people live in developing countries. Disabled people face challenges in health, education, communal participation and accessibility (WHO, 2011). Policies in the field of disability studies are supposed to protect the rights of disabled people and their accessibility to services such public transportation, housing, health, education and other important life necessities. Apart from Convention on the rights of persons with disabilities, countries have their own local policies and practices to help disabled people. In this regard, some policies may work in one country and may or may not work in other (Njeru et al., 2017). For instances, American with Disabilities Act (1990) has proved an important document to help disabled people in America. It has brought positive changes in providing accessible environment, ending up discrimination and developing a positive language discourse regarding disabled people (Coastal Bend Centre for Independent Living, 2009).

However, legislations, especially in third world countries proved to be words on documents and could not bring a positive change in the lives of disabled people. International efforts for the development and wellbeing of disabled are very important in the field of policy development for disabled people. In this regard, Convention on the Rights of the Child (1989) and Education for All (1994) are historical measures taken by international community to include individuals, including those with disabilities, in the socio-educational spheres (Whitburn, 2015). While, deceleration of 1981 as the international year of disabled persons and adoption of the historical convention "Convention on the Rights of Persons with Disabilities (CRPD) 2006 by United Nation are worth to note in terms of historical development, implications and future direction. Pakistan is a signatory of CRPD which means the state has the obligations to help disabled people in Pakistan as per the articles of CRPD (Ahmad, Khan and Nasem, 2011).

Furthermore, many countries, including Pakistan, have drawn on United Nation polices to form their domestic laws and policies. In this connection, The Australian Disability Standards for Education (2005-6), the UK Equality Act (2010) and American with Disabilities Act (1990) are the prime examples. The value of such efforts and policies cannot be underestimated because of 
considerable positive implications that address inclusion, civil rights, equality and just society (Whitburn, 2015). However, the enactment of laws under local condition and reflecting the localised discourse is the new emerging field of study and research.

\section{The Declaration on the Rights of Disabled Persons 1975}

The declaration on the Rights of Disabled Persons, adopted in 1975, was a ground-breaking achievement in terms of recognition of human rights for disabled persons. It stressed and focused on the inherent dignity of disabled people and discouraged non-discrimination attitude and practices in various spheres of communal affairs. It also aimed for disabled people to achieve self-reliance and quality of living (United Nation, 1975). This declaration defined disabled person as "any person unable to ensure by himself or herself, wholly or partly, the necessities of a normal individual and/or social life, as a result of deficiency, either congenital or not, in his or her physical or mental capabilities" (United Nation, 1975: 1). Therefore, The Declaration on the Rights of Disabled Persons, 1975 incorporated a welfare-oriented approach that disabled people need assistance to be functional in society and need assistance in coping with disability for the social inclusion (United Nation, 1975).

\section{United Nations Convention on the Rights of Persons with Disabilities, 2006 (CRPD)}

The United Nations convention on the rights of persons with disabilities (UNCRPD/CRPD) was adopted by the General Assembly of UN in 2006 and it came into force on May 2008. As of June 2017, 174 states parties have ratified the CRPD (United Nation, 2019). The optional protocol of CRPD was established and in line with these protocols, state parties recognise and agree the legitimacy and competence of the Convention committee to assess, monitor and facilitate the communications from individuals or groups who claimed to be the victims of discrimination or violation of CRPD by the state parties (Broderick,2015). This convention is of immense and historic importance for inclusive society and it is being considered the first legally binding international treaty by which communities are able to hold their respective states for the enforcement of its articles and promote the quality of life of disabled people(Lang, 2009). Moreover, CRPD is a historical document that explains and clarifies disability from human rights perspective. The pivotal aspect of CRPD is to respect the inherent dignity of disabled people and equality in the same way as non-disabled people. This treaty could end the discrimination against disabled people in various sphere of life and provide a maximum possible support for the welfare of disabled people (Degener, 2017). 
United Nation CRPD is the outcome of a long- 30 years efforts and coordination among UN, disabled people organisations (DPO) and civil societies. In this regard, the UK based disabled academics and activists played a key role to materialize, their efforts and uncanny advocacy into the establishment and adoption of CRPD (UPIAS, 1976; Albrecht, 1976; Barnes, 1991). Moreover, the era of 1980s witnessed the emergence of disability movement, therefore, in 1981, People's International established (Driedger, 1989). This period also witnessed the entablement of disabled people organisations (DPO) which played a crucial role in the advocacy of disabled people. These DPOs are run by disabled people aiming at provision of services and income generation (Coleridge, 2007). Similarly, in 1982 the General Assembly of United Nation initiated the World Program of Action regarding disability. The main purpose of the program was to develop strategies for the prevention of disability and rehabilitation of disabled people. Consequently, all these effort in inter alia led to the adoption of CRPD (Helander, 1993).

\section{Review of Literature}

CRPD possesses immense importance for disabled people and international communities where disabled people live in a sizable proportion. It is the first comprehensive international legal-binding instrument which reflects the global support and agreement to support and develop disabled people across the globe. It urges the members states to fulfil their obligations as defined and explained in the articles, towards disabled persons. CRPD establishes a committee of experts of disability to assess and monitor the implementation of the mandate provided by the 50 articles of at international level (Guernsey, 2007). Furthermore, CRPD is a unique international treaty signed and ratified by high number of state parties within a short period of time. The adoption and development of CRPD was a participatory process where civil society, disabled people and their organisations participated in the whole negotiation process (Broderick, 2015).

Globally, CRPD through its committee, has improved living condition of disabled people up to great extent. It is being considered a great achievement by disabled people in different part of the world. However, lack of proper implementation mechanism at local level in different part the world is a matter of concern for many disabled people. It is considered a paradigm shift from medical model to social legal model which realized the rights of disabled people and promote their inherent dignity.

CRPD recognises the barriers created by society and the exclusion of disabled people by these societal barriers. In this regard, physical environmental barriers and negative attitudes are being considered the obstacles in the development of disabled people (United Nation, 2007). Therefore, it mainly urges the state parties 
to remove these barriers for the inclusion of disabled people and development of inclusive society (United Nation, 2007). CRPD acknowledges and addresses the civil, political rights, cultural and economic rights and clarifies their application in detail. Therefore, it provides disability rights a fixed and firm place in human rights mechanism and its discourse (Colm O'Cinneide, 2009).

Furthermore, the inclusion of Non-governmental Organisation is another important step for the promotion and implementation of CRPD. This has resulted in an unprecedented participation and involvement of civil societies, which boost up the process of dialogue, mutual trust and cooperation. The involvements NGO in different countries of the world is being considered a crucial step in the empowerment and development of disabled people. In this way, the CRPD does not only address disabled people, but it also include them in decision making process (Kayess \& French, 2008).

The Convention depicts the first legal-binding framework that justifies and seeks to ensure the protection of human rights of disabled people. The adoption of the CRPD was welcomed globally (Broderick, 2015). Similarly, The United Nation General Secretary has called it "heralded the dawn of a new era- an era in which disabled people will no longer have to endure the discriminatory practices and attitude that have been permitted to prevail for all too long" (Mental Disability Advocacy Center, 2011). However, it is worth to mention here that disabled persons are still facing challenges in many spheres of life. The lack implementation on part of state parities is evident which need to be monitored and a way forward is needed to realize the themes, philosophy and articles of CRPD(OHCHR, 2019).

CRPD is considered the first and comprehensive treaty of the 21 century. It is a great step towards changing the prevailing negative attitude against disabled people. The treaty views disability from a rights-based approach. It reflects the social model of disability which depicts that barriers disabled people face are not the result of their impairment but other factors such as societal negative attitude and built environment exclude disabled people. Furthermore, CRPD asserts that full inclusion and access to quality of life and services are the rights of disabled people which must be protected and promoted (Heymann, Stein and Moreno, 2014). The CRPD promotes and advances the legality of disability reforms by involving disabled people and using a human rights framework. In this regard, CRPD urges that disabled people should not be considered object but subjects who deserve respect, dignity and enjoyment of all human rights (WHO, 2011).

Pakistan has ratified CRPD in the year 2011, following government's commitment to promote social, political, economic and civil rights of disabled people. However unfortunately, not much has changed as direction set by the 
framework of CRPD and yet disabled people in Pakistan are being excluded from education, health service, jobs, rehabilitation and other spheres of society. There is no proper mechanism to redress their issues and problems on a permanent basis and organised way (Heymann, Stein \& Moreno, 2014).

\section{Method and Material}

This research study is based on the analysis available literature on legislation and policies regarding disabled people in Pakistan. Systematic review of literature on policies development on disabled people was studied and carried out with the help of secondary information by books, journals, articles, library and newspaper. Online internet searches were done to search out relevant material regarding the topic.

\section{Disability Policy measure in Pakistan}

According to Helping Hand (2012), there are 5.034 million disabled people in Pakistan. This sizeable proportion of disabled people in Pakistan is more than the individual population of Lebanon, New Zealand and Kuwait. Furthermore, it is worth to note here that disabled population in Pakistan is more that the cumulative population of Hyderabad, Peshawar and Multan (Helping Hand, 2012). Government of Pakistan, keeping view the sizeable population of disabled people in the country, enacted laws to address the issues of this downtrodden people. In this regard, After UN adoption of CRPD, realising the importance of human rights of disabled people, Pakistan has signed and ratified the UNCRPD in 2010. Since then, Pakistan has introduced comprehensive policy and enacted laws in line with CRPD, however, before the ratification of CRPD, Pakistan took sporadic measures as well to bring disabled people in mainstream communal activities. Below are the policy measures taken by Pakistan in this regard.

\section{Disabled Persons (Employment and Rehabilitation) Ordinance, 1981}

After the declaration of the year 1981 as international year of Disabled Person, Pakistan in the same year, promulgated "The Disabled Persons Employment and Rehabilitation Ordinance 1981 (Disabled Persons Ordinance, 1981). Under this ordinance, Ministry of social welfare and special education was established. In addition, National Council for the rehabilitation of disabled people came into being which supposed to devise policies with respect to rehabilitation of disabled people and their employment. Furthermore, medical assessment of disabled people was also the mandate of National council (Ahmad, Khan and Nasem, 2011). Similarly, through this ordinance, provincial authorities were given the 
tasks to implement policies developed by National Council and to take initiatives regarding rehabilitation and wellbeing of disabled people and their employment (Disabled Persons Ordinance, 1981). Moreover, the most important theme in the ordinance is allocation of quota for disabled people. Under the ordinance, initially, once percent quota was allocated which was increased to two percent after 1998 census through a special directive of then government. The two percent quota allocation is applicable in all public and private sector organizations (Ahamd, Khan, Nasem, 2011). However, again, this could not change and improve the condition of disabled people in Pakistan. The two percent quota seems good in papers but in practices it has no effective implications that can improve the status of disabled people regarding employment.

Furthermore, under the ordinance, when calculating the percentage of marks for the post/employment, the fraction of 0.5 shall be considered as whole for disabled people. Similarly, establishment of training centres for disabled people is an important theme of the 1981 ordinance. Under the ordinance, federal government is made responsible to maintain and release and fund for the implementation welfare measures given in the ordinance (Disabled Persons Ordinance, 1981).

\section{The National Policy for Persons with Disabilities, 2002}

As a response to second disability decade, declared by UNESCAP, Government of Pakistan after long discussion with the relevant stakeholders in 2002, devised The National Policy for Persons with disabilities. Many key stakeholders such as NGOs, ministries of housing and work, labour and manpower and science and technology participated in the consultation process. This document provided a plan and guidelines to help and empower disabled people across the country (Ahmad, Khan and Nasem, 2011). The vision of National Policy for Persons with Disabilities is that by 2025, a conducive environment for disabled people will be provided which will allow the full realisation of their potential through inclusive mainstreaming with the help government, civil society and NGOs (Government of Pakistan, 2002).

Furthermore, the goal of National Policy for Persons with Disabilities is to empower disabled people, regardless of their gender, race, caste, creed and other condensation for the realisation of their full potential in all sphere of life. The main areas of focus of this policy document are prevention of disabilities, detection and diagnostic system for the prevention and intervention strategies, intervention through developing a referral mechanism to multi professional teams at local and district level, counselling, genetic counselling and family guidance (Government of Pakistan, 2002). In addition, National Policy for persons with 
Disabilities also target the area of special education and envisaged to make it an integral part of mainstream education in Pakistan. While training provision for social welfare workers, doctors and other related professional is also the focus of the policy document. Similarly, integration and mainstreaming of disabled children through alignment of policies of federal, provincial and districts government at the level of relevant ministries and departments, changes in the curriculum and provision of specialised assistive devices are also important target areas of this policy document (Government of Pakistan, 2002).

Moreover, vocational trainings, employment and rehabilitation, research development, advocacy and mass awareness, sports and recreation for disabled adult and children, promoting disability friendly design of buildings, park and places, development of institutional mechanism and involvement of community and family for the development of disabled people are the area of intervention, mentioned in National Policy for Persons with Disabilities (Government of Pakistan, 2002).

\section{National Plan of Action (2006)}

In response to the 1990 World Summit for Child, Government of Pakistan following its commitment to the summit, prepared National plan of action in 1990-91. This was prepared though a process of coordination by National Commission for Child Welfare Development, under the supervision of ministry of Social Welfare. Later, the draft was revised, and a comprehensive document was developed with inclusion of civil society, governmental departments, academia and other experts of developmental sectors. Therefore, the Federal Cabinet officially endorsed the document and adopted it on May 2006. The focus of National Plan of Action is social mobilization, advocacy, networking, political commitment, capacity building, awareness, provision of resources and strengthen functional struct ion and systems related to disability (Network of Organization working for PWDs, 2008). Furthermore, National Plan of Action used an integrated approach by utilising the resources for accessibility and provision of equal opportunities for disabled people (Ahmad, khan, Nasem, 2011). National Plan of Action devised short term and long plans for the inclusion and development of disabled people in many spheres of life (Network of Organization working for PWDs, 2008).

\section{Special Citizen Act 2008}

Special citizen Act was promulgated by Government in 2008. The act aims at providing and promoting accessible environment such as allocation of seats in public transportations and constructions footpaths for wheelchairs users and visually impaired people. Traffic police are bound to take necessary measures and 
help disabled people to cross the road. Government shall make sure accessibility measure before construction of buildings in public and private sectors especially Bank, hospital, shopping centres, police station, railway stations, and Airport (Special Citizens Act, 2008; Ahmad, Khan \& Nasem., 2011).

\section{Special Citizens (Right to Concession in Movement) Act, 2009}

The Special Citizen Act was promulgated by government in 2009. Through this act, authorities are bound to provide concessional fare for disabled persons in private and public transportations. The act seeks half fare charges for disabled people in railway and other public transport in Pakistan (Special Citizen Act, 2009).

After $18^{\text {th }}$ constitutional amendment, disability became a provincial subject and provincial governments in each province prepared amendment bill and policy documents. In this regard, Khyber Pakhtunkhwa provincial government plans to increase the two percent job quota to four percent. While Government of Punjab already proposed legislation to increase the two percent quota in job to three percent. Similarly, Baluchistan Government has passed a bill regarding the welfare of disabled people named as "The Baluchistan Persons with Disabilities Act, No II of 2017". The bill aims to promote inclusive environment for disabled people and protection of their rights (The Baluchistan Persons with Disabilities Act, 2017) of measure taken by federal and provincial governments for the wellbeing of disabled people, there is still a lot more to be done. Disabled people face discrimination, inaccessibility, lack of education facilities, lack of facilities in transports, in inter alia.

Furthermore, it is interesting to state that for the general election agenda, all the mainstream political parties included the development of disabled people. In this regard, Pakistan People Party and Pakistan Tehrik-e-Insaf also manifested the implementation of United Nation Convection on the Rights of Persons with Disabilities. While Pakistan Muslim League (N) focused on quality education and general human rights of disabled persons. Similarly, Awami National Party and Muttahida Quam iMovmen focused awareness regarding and provision of accessible environment for disabled people (ASER Pakistan, 2016).

\section{Dynamics of Disability}

Disability, directly or indirectly, is a part of human condition. Every individual at some point of time experience difficulties in functioning. Every society has adopted its own way to deal with problem of disabilities. Historically, disabled people were segregated and placed in separate institutions or special schools. 
However, policies have shifted towards a more inclusive approach and interactive approaches has replaced the dominant medicalised understating of disability (World Health Organisation, 2011). Disabled people are diverse and heterogenous group and disability experience may interaction of health condition, environmental factors and personal factors such race, colour, gender etc. The visible groups in disabled people who experience stereotypes, are visually impaired people, hearing impaired people and wheelchair users (McLaughlin MJ et al, 2008). Furthermore, disability can be congenital or losing limbs in war or accident. It also encompasses individual with arthritis, or person with old age experiencing dementia in inter alia (Fisher \& Meyer, 2002).

Disability has a direct or indirect link with poverty and development. In this regard, disability produces poverty and poverty produces disability. Both the factors increase the risks of occurrence disability and poverty. Therefore, families with a disabled member are more likely to face social and economic problems and disadvantages than families without disabilities. The onset of disability may exacerbate the socio-economic crisis of an individual and can have a devastating impact on employment, education, health, and high expenditures regarding disability (Jenkins \& Rigg, 2003). Research on disability in developing countries depicts that disabled people are vulnerable with respect to education and employment opportunities. Studies find that disabled people have lower employment rated and attainment of educational goals as compared to their nondisabled counter parts (WHO, 2011).

Furthermore, in education sector, disabled children are less likely to start schooling and school going have less chances of staying and get promoted in schools. The correlation of children and adult with disabilities is much stronger which means educational outcome is affected by disability (Filmer, 2008). Similarly, violence against disabled students, by staff and students is evident in educational institutions (UN, 2005). Disabled students become an easy victim of violent acts including social isolation, verbal abuse and physical abuse and threats. The fear of bullying further discourages disabled students to go school or college. It is therefore, disabled students often prefer to take admission in special education (Watson, 1998).

In developing countries, including Pakistan the most noticeable cause of disability is socio-economic conditions. Poor nutrition, limited access to medicines, maternity care, hazardous working environment, bad sanitation, poor hygiene and lack of information cause disability. While war and natural disaster also play a contributing role in the causation of disability (Fletcher and Hurst, 1995). Research studies find that disability causes poverty and poverty causes disability. In this regard, the ratio of disability is more than twice as high in the lowest income countries. Disability in developing countries leads to exclusion of 
disabled people from communal activities, employment and education. Therefore, disabled who are denied of education are unable to get employment pushes them further to the vicious cycle of poverty (DFID, 1997).

Disabled people are the largest underestimated and ignored minority. Like other developing countries, disabled people in Pakistan face barriers in many spheres of life. Disabled people experience inaccessible environment ranging from physical inaccessibility to inaccessible information such braille or sign languages. Furthermore, societal negative attitude in Pakistan, further exacerbates the vulnerability of disabled people. Pakistan in its official documents use the terms as mentally retorted, insane, crippled etc, which show the attitudinal problems in society. In developed world, these terminologies have changed to people first language (Heymann, Stein \& Moreno, 2014).

Furthermore, the two percent quota approach failed in Pakistan. Majority of jobs are available in informal sectors, in which quota are irrelevant. Furthermore, if a disabled person sues any discrimination, the flawed legal system makes it difficult for them to win their legal battle even at the expense of huge financial loss necessary for the legal process in the country. Moreover, the self-employment cannot be underestimated because it is a biggest share of economy and again quota system is irrelevant here (Heymann, Stein \& Moreno, 2014). Disability situation in Pakistan seems worsen when it comes to the labour force participation of disabled women. Disabled women face greater barriers and challenges in the workforce or employment. Public transport is almost inaccessible while travelling by taxi or auto-rishkaw is difficult too. Therefore, disabled women are heavily dependent on their families to move around and this make them stagnant and passive and it is very difficult to find and avail opportunities in such conditions (Heymann, Stein \& Moreno, 2014).

It is evident from literature that disabled people face numerous challenges and problems in their day-to-day affairs. To address these issues, national and international efforts have been made but with limitations. Policies in the field of disability studies are supposed to protect the rights of disabled people and their accessibility to services such public transportation, housing, health, education and other important life necessities Apart from Convention on the rights of persons with disabilities, countries have their own local policies and practices to help disabled people. There are gaps in implementation and flaws in some legislations. Countries who have ratified CRPD must fulfil their commitment to protect the rights of disabled people. Disabled people are present in every country and society in sizeable proportion and their protection and development means developing a larger portion of society. In this regard, disabled people 
need more services, quality education, accessible environment, and full inclusion in every spheres of life.

\section{Conclusions}

Policies in the field of disability studies are supposed to protect the rights of disabled people and their accessibility to services such as public transportation, housing, health, education and other important life necessities. Apart from Convention on the rights of persons with disabilities, countries have their own local policies and practices to help disabled people. In this regard, some policies may work in one country and may or may not work in other. However, legislations, especially in third world countries, including Pakistan, proved to be words on documents and could not bring a positive change in the lives of disabled people. International efforts for the development and wellbeing of disabled are very important in the field of policy development for disabled people. Government of Pakistan, keeping view the sizeable population of disabled people in the country, enacted laws to address the issues of this downtrodden people. In this regard, After UN adoption of CRPD, realising the importance of human rights of disabled people, Pakistan signed and ratified the UNCRPD in 2010. Since then, Pakistan has introduced comprehensive policy and enacted laws in line with CRPD, however, before the ratification of CRPD, Pakistan took sporadic measures as well to bring disabled people in mainstream communal activities. In this regard, Pakistan enacted laws such Disabled Persons (Employment and Rehabilitation) Ordinance, 1981, The National Policy for Persons with Disabilities, 2002, National Plan of Action (2006), Special Citizen Act, 2008 and Special Citizens (Right to Concession in Movement) Act, 2009. However, these policies could not bring about changes in the lives of disabled people. There is no proper mechanism at national and local level to implement the policies developed for the wellbeing of such downtrodden people.

\section{Reference}

Ahmad, M., Khan., and Nasem, F. (2011). Policies for Special Persons in Pakistan: Analysis of Policy Implementation. Berkeley Journal of Social Sciences, vol.1:2, pp.233-242.

Albrecht, G. (Ed.). (1976). The Sociology of Physical Disability and Rehabilitation. Pittsburg: University of Pittsburg Press.

ASER Pakistan, 2016 Measuring SDGs for Inclusion, Learning \& Equity Lessons from ASER Pakistan, pp.1-12. http://aserpakistan.org/document/2018/ external_publications/aserpakistan_Disability_booklet.pdf 
Barnes, C. (1991). Disabled People in Britain and Discrimination. London: Hurst and Co.

Broderick, A. (2015). The Long and Winding Road to Equality and Inclusion for Persons with Disabilities : The United Nations Convention on the Rights of Persons with Disabilities. Maastricht: Intersentia.

Coastal Bend Center for Independent Living. (2009). About the CBCIL. Retrieved on June $18^{\text {th }}, 2019$, from http://www.cbcil.org/about.htm.

Coleridge, P. (2007). Economic Empowerment. In T. Barron, \& P. Amerena (Eds.), Disability and Inclusive Development. London: Leonard Cheshire International, pp.111-152.

Colm O'Cinneide (2009). Extracting Protection for the Rights of Persons with Disabilities from Human Rights Frameworks: Established Limits and New Possibilities in Oddn Mjll Arnardttir and Gerard Quinn eds, The UN Convention on the Rights of Persons with Disabilities: European and Scandinavian Perspectives (Martinus Nijhoff Publishers, Boston, 163.

Degener, T. (2017). 'A New Human Rights Model of Disability', in V. Della Fina, R. Cera \& G. Palmisano (eds.), The United Nations Convention on the Rights of Persons with Disabilities: A Commentary, pp. 41-60, Springer, Cham, Switzerland.

Department for International Development, (1997) Eliminating World Poverty: A challenge for the 21 st Century. White Paper on International Development. London: The Stationary Office.

Disabled Persons (Employment and Rehabilitation) Ordinance. (1981). Government of Pakistan.

Driedger, D. (1989). The Last Civil Rights Movement: Disabled Peoples' International. New York: St. Martin's Press.

Filmer, D. (2008). Disability, Poverty and Schooling in Developing Countries: Results from 14 Household Surveys. The World Bank Economic Review, vol.22:1, pp.141-163.

Fisher, M. \& Meyer, L, H. ( 2002). Development and Social Competence after Two Years for Students who Enrolled in Inclusive and Self-Contained Educational Programs. Research and Practice for Persons with Severe Disabilities, vol.27, pp.165-174. 
Fletcher, A. \& Hurst, R. (1995), Overcoming Obstacles to the Integration of Disabled People, London: Report for the World Summit on Social Development, London, DAA.

Government of Pakistan, (2002). The National Policy for Persons with Disabilities. Social Welfare and Special Education, Islamabad.

Guernsey, K., Nicoli, M. \& Ninio, A. (2007). Convention on the Rights of Persons with Disabilities: It's Implementation and Relevance for the World Bank. Discussion Paper.

Helander, E. (1993). Prejudice and Dignity - An Introduction to CommunityBased Rehabilitation. New York: United

Helping Hand. (2012). Persons with Disabilities statistics in Pakistan. Agha Gee, Islamabad.

Heymann, J., Stein, M. A. \& Moreno, G. eds. (2014). Moving from the Margins, Mainstreaming Persons with Disabilities in Pakistan. A Custom Research Report Produced for the British Council. Eds, Disability and Equality at Work. Oxford University Press.

Jenkins, S. P. \& Rigg, J. A. (2003). Disability and Disadvantage: Selection, Onset and Duration Effects. London, London School of Economics, Centre for Analysis of Social Exclusion.

Lang, R. (2009). The United Nations Convention on the Right and Dignities for Persons with Disability: A Panacea for Ending Disability Discrimination? European Journal of Disability, vol.3, pp.266-285.

McLaughlin M.J. et al. (2008). The Education of Children with Disabilities and Interpretations of Equity: A Review of Policy and Research. New York, Teachers College, Columbia University.

Mental Disability Advocacy Centre. (2011). Building the Architecture for Change: Guidelines on Article 33 ofthe UN Convention on the Rights of Persons with Disabilities. Nations Development Programme.

Njeru, L, M., Gichuhiz, D. \& Ombaka, B. (2017). An Assessment of the Influence of Disability Legislation Awareness on Employability of Persons with Disabilities in Post Secondary Institutions in Kirinyaga County, Kenya. Management and Economics Research Journal, vol.3, pp.91-97. 
O’Connell, C., Finnerty, J. \& Egan, O. (2008). Hidden Voices, Combat Poverty Agency, Poverty Research Initiative, Dublin.

OHCHR. (2019) United Nation Human Rights Office of the High Commissioner. Also available at https://www.ohchr.org/EN/HRBodies/CRPD/Pages/ ConventionRightsPersons WithDisabilities.aspx

Kayess, R. \& French, P. (2008). 'Out of Darkness into Light? Introducing the Convention on the Rights of Persons with Disabilities'. Human Rights Law Review, vol.8:1, pp.1-34.

Special Citizens (Right to Concessions in Movement) Act, 2009; Government of Pakistan.

Special Citizens Act.(2008). Government of Pakistan.

UNICEF. (2012). The Right of Children with Disabilities to Education: A RightsBased Approach to Inclusive Education Position Paper.

United Nation ( 1975). Declaration on the Rights of Disabled Persons. GA Res 3447 (XXX), UN GAOR, 30th sess, 2433rd plen mtg, Supp No 34, United Nation Doc A/Res/3447/(XXX) (9 December 1975).

United Nation. (2005). UN Secretary-General's Report on Violence against Children. Thematic Group on Violence against Children. Findings and Recommendations. Summary Report. New York, United Nations Children's Fund.

United Nation. (2007). United Nations Office of the High Commissioner for Human Rights and Inter-Parliamentary Union, From Exclusion to Equality - Realizing the Rights of Persons with Disabilities. Geneva, 4.

United Nations, (2019) Treaty Collection. Convention on the Rights of Persons with Disabilities. Human rights. https:// treaties. un. org/ pages/ ViewDetails.aspx $? \quad$ src $=$ TREATY\&mtdsg_no $=\quad I V-15 \&$ chapter $=4 \&$ clang=_en (accessed 7 Jun 2019).

UPIAS (1976). Fundamental Principles of Disability. London: UPIAS.

Watson $\mathrm{N}$ et al. (1998). Life as a Disabled Child: Research Report. Edinburgh, University of Edinburgh. 
Whitburn, B. (2015). National and International Disability Rights Legislation: A Qualitative Account of its Enactment in Australia, International Journal of Inclusive Education, vol.19:5, pp.518-529.

WHO. (2011). World Report on Disability. Geneva.

Razia Gul is Student of L.L.M in the Department of Law, Abdul Wali Khan University, Mardan, Pakistan. 